\title{
Oligotrophic oceans and minimalist organisms: collapse of the Maastrichtian marine ecosystem and Paleocene recovery in the Cretaceous-Tertiary sequence of New Jersey
}

\author{
W.B. Gallagher ${ }^{1}$ \\ 1 New Jersey State Museum, TRENTON, New Jersey 08625-0530, USA; and Department \\ of Geological Sciences, Rutgers University, PISCATAWAY, New Jersey 08855, USA; \\ e-mail: william.gallagher@sos.state.nj.us
}

Manuscript received: June 2000; accepted in revised form: October 2001

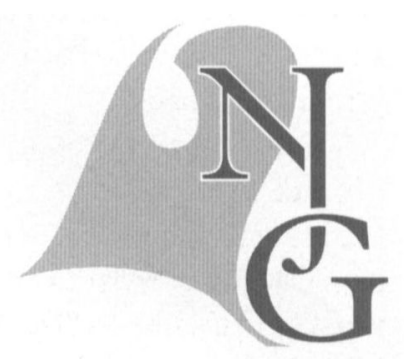

\begin{abstract}
The inner Atlantic Coastal Plain of New Jersey reveals exposures of fossiliferous Maastrichtian and Danian deposits. Recent fossil discoveries in this interval are here reported, and placed in the context of Cretaceous/Tertiary (K/T) faunal changes. The exposure at the Inversand Pit at Sewell (New Jersey) is the last active marl mine in the region, and stands as an important reference section for the many significant discoveries of vertebrate fossils produced by the marl mining industry at its zenith. Changes in planktonic populations across the $\mathrm{K} / \mathrm{T}$ boundary are related to Maastrichtian/Danian marine ecosystem community reorganisation, by demonstrating changes in abundance of dominant marine invertebrates in successive fossil assemblages. Marine invertebrates with non-planktotrophic larval stages were briefly the commonest fossils preserved in the Danian sediments of this region. Late surviving examples of Cretaceous fauna now restricted to the Indo-Pacific region may imply biogeographic changes linked to the $\mathrm{K} / \mathrm{T}$ mass extinction event.
\end{abstract}

Keywords: Maastrichtian, Danian, K/T boundary, faunal assemblages, New Jersey

\section{Introduction}

New Jersey played a prominent role in the early development of the science of palaeontology in North America, and although the fossiliferous deposits of the New Jersey Coastal Plain have been studied for two centuries, new discoveries and interpretations are still emerging from these classic sections. The inner Coastal Plain of New Jersey is underlain by deposits of Late Cretaceous and Early Cenozoic age (Fig. 1); these beds contain an abundant record of life at the end of the Mesozoic Era. Some of the most fossiliferous deposits are the beds of glauconite which were widely mined as fertiliser in the nineteenth century.

The greensand marl pits produced many of the earliest discoveries of dinosaurs and other vertebrate fos- sils in North America. At Haddonfield (Camden County), the site of the discovery of Hadrosaurus foulkii was an old marl pit that yielded the most complete skeleton of a dinosaur known at that time (Leidy, 1858). Since then, the marl deposits have yielded numerous specimens to private and professional collectors. Fossils of Maastrichtian age are found in the Monmouth Group, consisting of the Mount Laurel, Navesink, Red Bank and Tinton formations, in ascending order (Table 1). Typical Maastrichtian taxa include the bivalve genera Exogyra, Pycnodonte, and Agerostrea, belemnite guards (Belemnitella americana), the small brachiopod Choristothyris plicata, and shark teeth of several species [Scapanorhynchus texanus, Squalicorax pristodontus, Cretolamna appendiculata], plus scrappy remains of various vertebrates.

Recently, Miller et al. (1999) have interpreted the 


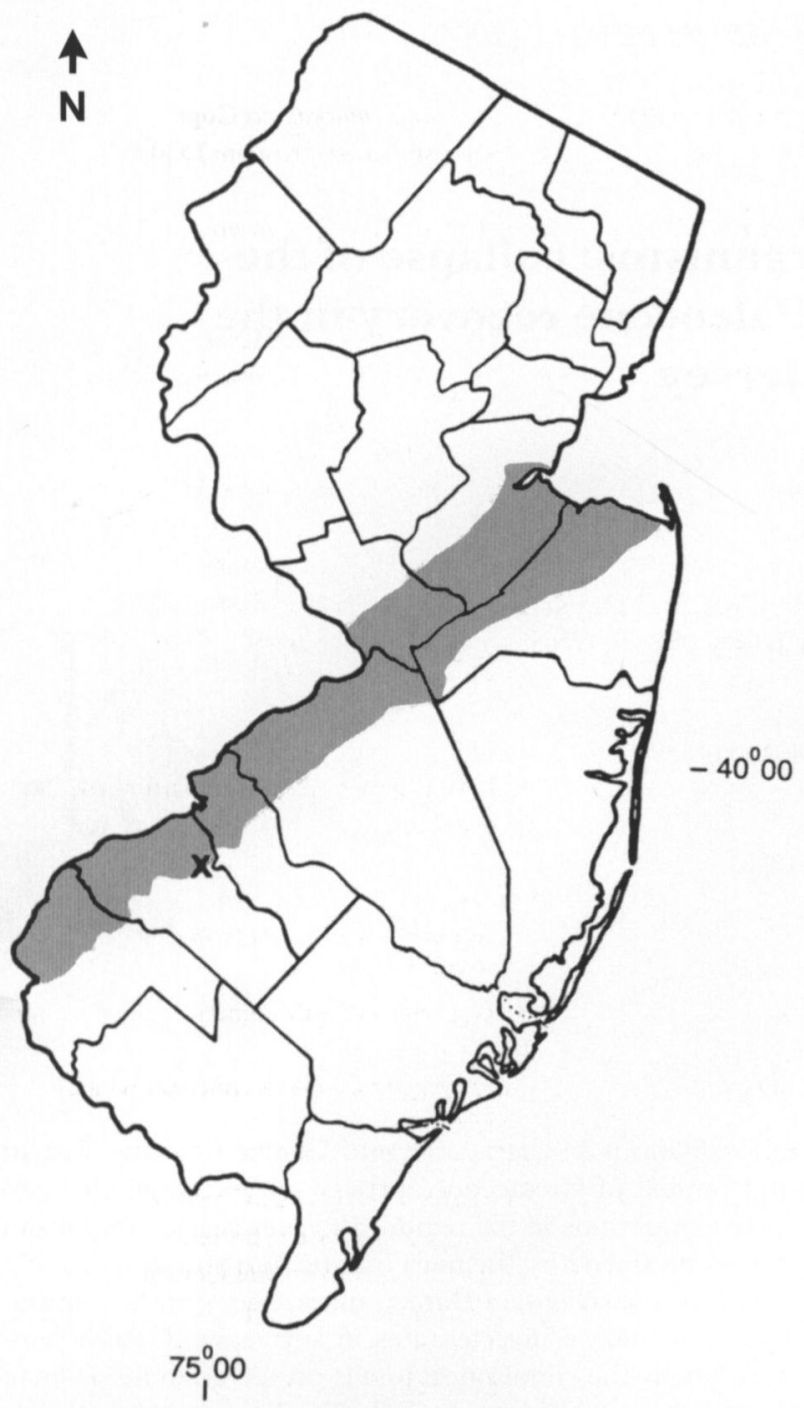

Fig. 1. Outcrop belt of Upper Cretaceous-Paleocene sediments in the Atlantic Coastal Plain of New Jersey; the cross marks the location of the Inversand Pit.

Mount Laurel-Navesink contact as a sequence boundary caused by glacio-eustatic sea level fall, with the novel conclusion that continental glaciation was a driving sea level change as far back as the Late Cretaceous. Certainly, our taphonomic studies support the idea of falling sea level in the upper Mount Laurel, and the contact between the two formations is quite abrupt. Just below the contact, a concentration of fossils comprises abundant fossil vertebrate remains, primarily chondrichthyan and mosasaur material, as well as an invertebrate assemblage dominated by inoceramids and ammonites. The superjacent Navesink Formation is a transgressive unit containing several oyster bed assemblages in its greensand marl. Recently discovered, noteworthy finds in the Monmouth Group marl beds of Late Cretaceous age include a hollow coelurosaurian long bone shaft, the first lungfish jaw plate known from the Upper Cretaceous of North America (Parris et al., 2001), and a possible
Table. 1. Stratigraphy of Atlantic Coastal Plain in New Jersey.

\begin{tabular}{|c|c|c|c|}
\hline PERIOD & ЕРОСН & GROUP & FORMATION \\
\hline Quaternary & Pleistocene & & Cape May \\
\hline \multirow[t]{4}{*}{ Tertiary } & Pliocene & & Pensauken \\
\hline & Miocene & & $\begin{array}{l}\text { Cohansey } \\
\text { Kirkwood }\end{array}$ \\
\hline & Eocene & & $\begin{array}{l}\text { Shark River } \\
\text { Manasquan }\end{array}$ \\
\hline & Paleocene & Rancocas & $\begin{array}{l}\text { Vincentown } \\
\text { Hornerstown }\end{array}$ \\
\hline \multirow[t]{3}{*}{ Cretaceous } & Late & Monmouth & $\begin{array}{l}\text { Tinton } \\
\text { Red Bank } \\
\text { Navesink } \\
\text { Mount Laurel }\end{array}$ \\
\hline & & Matawan & $\begin{array}{l}\text { Wenonah } \\
\text { Marshalltown } \\
\text { Englishtown } \\
\text { Woodbury } \\
\text { Merchantville }\end{array}$ \\
\hline & & & $\begin{array}{l}\text { Magothy } \\
\text { Raritan }\end{array}$ \\
\hline
\end{tabular}

Table 2. Formations, dominant fossils, and reproductive types in the inner Coastal Plain K/T section of New Jersey.

\begin{tabular}{|c|c|c|}
\hline Horizon & Fossils & $\begin{array}{l}\text { Reproductive } \\
\text { type }\end{array}$ \\
\hline Vincentown & bryozoans & non-planktotroph \\
\hline Oleneothyris & brachiopod & non-planktotroph \\
\hline Hornerstown & sponges, brachiopods & non-planktotroph \\
\hline MFL & oysters, clams & planktotroph \\
\hline Navesink & oysters & planktotroph \\
\hline Mt Laurel (top) & clams & planktotroph \\
\hline Marshalltown & oysters & planktotroph \\
\hline
\end{tabular}

Cretaceous multituberculate incisor (Grandstaff et al., 2000).

The Red Bank and Tinton formations have limited areal extent in Monmouth County before pinching out to the southeast. In the southern part of the outcrop belt, the Navesink Formation is directly overlain by the Hornerstown Formation, the bulk of which is Danian in age. Paleocene deposits are combined into the Rancocas Group, including the Hornerstown and Vincentown formations. The Red Bank Formation has yielded Maastrichtian fossils, primarily the bivalve Cucullaea and shark teeth. The boundary between the inner Coastal Plain underlain by Upper Cretaceous and Lower Cenozoic strata, and the outer Coastal Plain composed of younger Cenozoic sedi- 
Table 3. Faunal list for the Inversand Pit, Mantua Township, Gloucester County, New Jersey.

\section{Navesink Formation (Maastrichtian)}

Porifera

Cliona cretacea Fenton \& Fenton

Brachiopoda

Choristothyris plicata (Say)

Bryozoa

indeterminate encrusting bryozoans

Bivalvia

Cucullaea antrosa Morton

Cucullaea neglecta $\mathrm{Gabb}$

Cucullaea vulgaris Morton

Glycymeris mortoni (Conrad)

Agerostrea nasuta (Morton)

Pycnodonte convexa (Say)

Gryphaeostrea vomer Morton

Exogyra costata Say

Trigonia mortoni Whitfield

Crassatellites vadosus (Morton)

Liopistha protexta (Conrad)

Spondylus (Dianchora) echinata (Morton)

Pachycardium spillmani (Conrad)

Solemya cf. lineolatus Conrad

Lithophaga ripleyana Gabb

Gastropoda

Lunatia halli Gabb

Gyrodes petrosus (Morton)

Turritella cf. vertebroides Morton

Anchura cf. abrupta Conrad

Anchura pennata (Morton)

Pyrifusus macfarlandi Whitfield

Turbinopsis curta Whitfield

Volutomorpha ponderos $a$ Whitfield

Nautilida

Eutrephoceras dekayi Morton

Ammonoidea

Baculites ovatus Say

Discoscaphites conradi (Morton)

Echinodermata

Hemiaster sp.

Chondrichthyes

Squalicorax pristodontus (Agassiz)

Odontaspis sp.

Osteichthyes

Enchodus ferox Leidy

Anomoeodus phaseolus (Hay)

indeterminate large teleost (?Xiphactinus)

Chelonia

Peretresius ornatus Leidy

indeterminate cheloniids

Squamata

Halisaurus platyspondylus Marsh

Mosasaurus maximus Cope ( $=M$. hoffman-

ni Mantell)

Mosasaurus sp.

Prognathodon rapax (Hay)

Dinosauria

Hadrosaurus minor Marsh

indeterminate ?lambeosaurine
Basal Hornerstown Formation (MFL)

\section{Brachiopoda}

Terebratulina atlantica Morton

Bivalvia

Nuculana stephensoni Richards

Cucullaea vulgaris Morton

Glycymeris mortoni (Conrad)

Gervilliopsis ensiformis (Conrad)

Pycnodonte dissimilaris

Gryphaeostrea vomer Morton

Veniella conradi Morton

Cardium tenuistriatum Whitfield

Etea delawarensis (Gabb)

Crassatellites vadosus (Morton)

Panopea decisa Conrad

Lithophaga ripleyana $\mathrm{Gabb}$

$X y$ lophagella irregularis (Gabb)

Gastropoda

Lunatia halli Gabb

Gyrodes abyssinus Morton

Turritella vertebroides Morton

Anchura abrupta Conrad

Volutoderma ovata Whitfield

Turbinella subconica Gabb

Turbinella parva Gabb

Pyropsis trochiformis (Tuomey)

Acteon cretacea Gabb

Nautilida

Eutrephoceras dekayi (Morton)

Ammonoidea

Baculites sp.

Pachydiscus (Neodesmoceras) sp.

Sphenodiscus lobatus (Tuomey)

Crustacea

cf. Hoploparia sp.

Chondrichthyes

Edaphodon stenobyrus (Cope)

Edaphodon mirificus Leidy

Ischyodus thurmanni Pictet \& Campiche

Squatina sp.

Squalicorax pristodontus (Agassiz)

Cretolamna appendiculata (Agassiz)

Odontaspis cuspidata (Agassiz)

indeterminate elasmobranchs (teeth, vertebrae)

Rhombodus levis Cappetta \& Case

Rhinoptera sp.

Myliobatis cf. leidyi Hay

indeterminate batomorphs (vertebrae)

Osteichthyes

Acipenser cf. albertensis Lambe

Enchodus ferox Leidy

cf. Bananogmus sp.

indeterminate teleosts (vertebrae)

Chelonia

Taphrosphys sulcatus Leidy

cf. Bothremys sp.

Adocus beatus Leidy

Agomphus turgidus Cope

Dollochelys atlantica (Zangerl)
Osteopygis emarginatus Cope

Peretresius cf. emarginatus Leidy

Crocodylia

Hyposaurus rogersii Owen

Diplocynodon sp.

cf. Procaimanoidea sp.

Bottosaurus harlani Meyer

Thoracosaurus neocesariensis (DeKay)

Squamata

Mosasaurus sp.

indeterminate mosasaurids

Aves

Telmatornis priscus Marsh

Paleotringa littoralis Marsh

Graculavis velox Marsh

indeterminate birds

Middle Hornerstown Formation fossil assemblage

Porifera

Peridonella dichotoma $\mathrm{Gabb}$

Cnidaria

Flabellum mortoni Vaughan

Brachiopoda

Oleneothyris harlani forma manasquani Stenzel

Bivalvia

Cucullaea macrodonta Whitfield

Ostrea glandiformis Whitfield

Crassatellites cf. littoralis Conrad

Caryatis veta Whitfield

Gastropoda

cf. Volutacorbis sp.

Nautilida

cf. Aturia sp.

Chondrichthyes

Edaphodon agassizi (Buckland)

Odontaspis sp.

Otodus obliquus (Agassiz)

Paleocarcharodon $\mathrm{sp}$

Chelonia

Dollochelys sp.

Crocodylia

Hyposaurus rogersii Owen

\section{Vincentown Formation}

Bryozoa

indeterminate encrusting bryozoans

Bivalvia

Polorthus tibialis (Morton) 


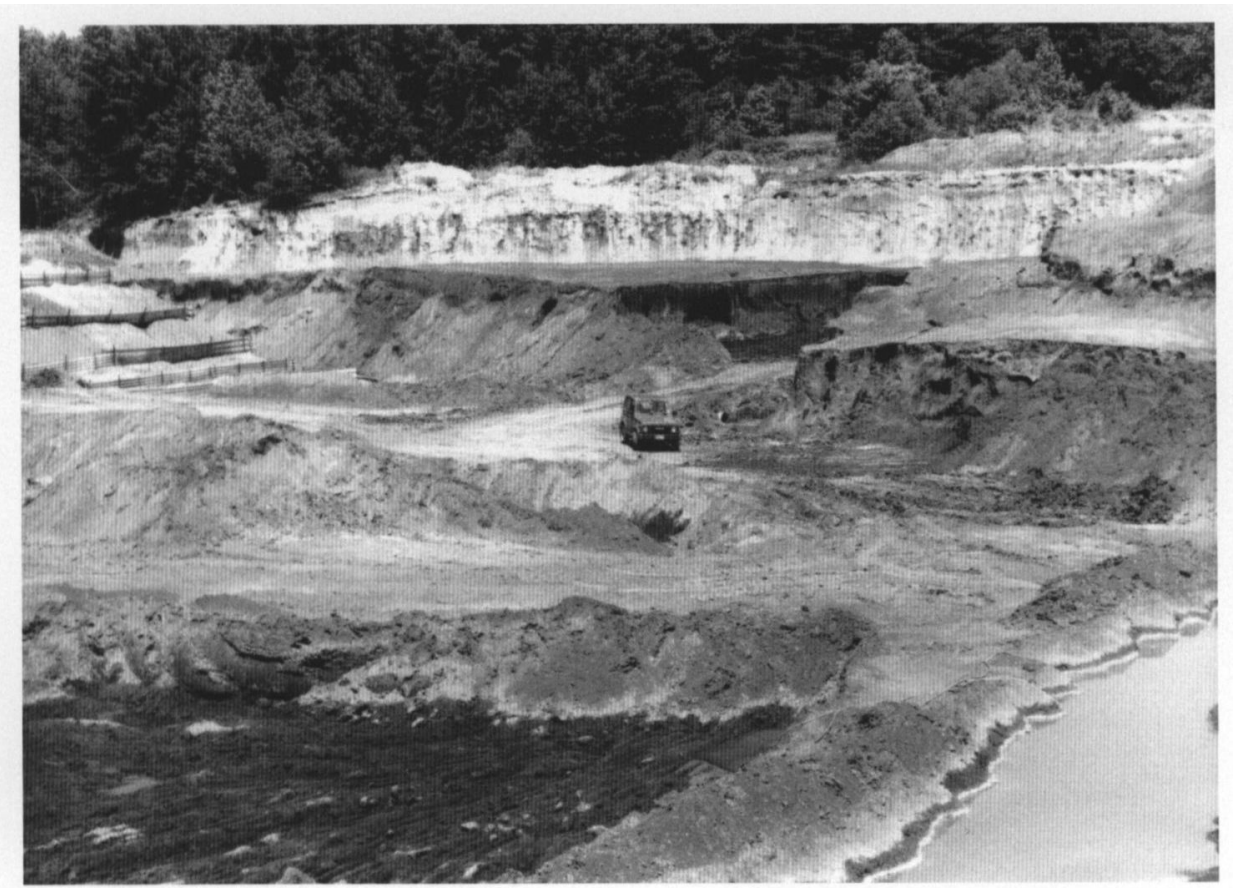

Fig. 2. Exposures of the Maastrichtian through Miocene section at the Inversand Pit, Sewell (New Jersey). The vehicle's tyres rest approximately on the $\mathrm{K} / \mathrm{T}$ contact.

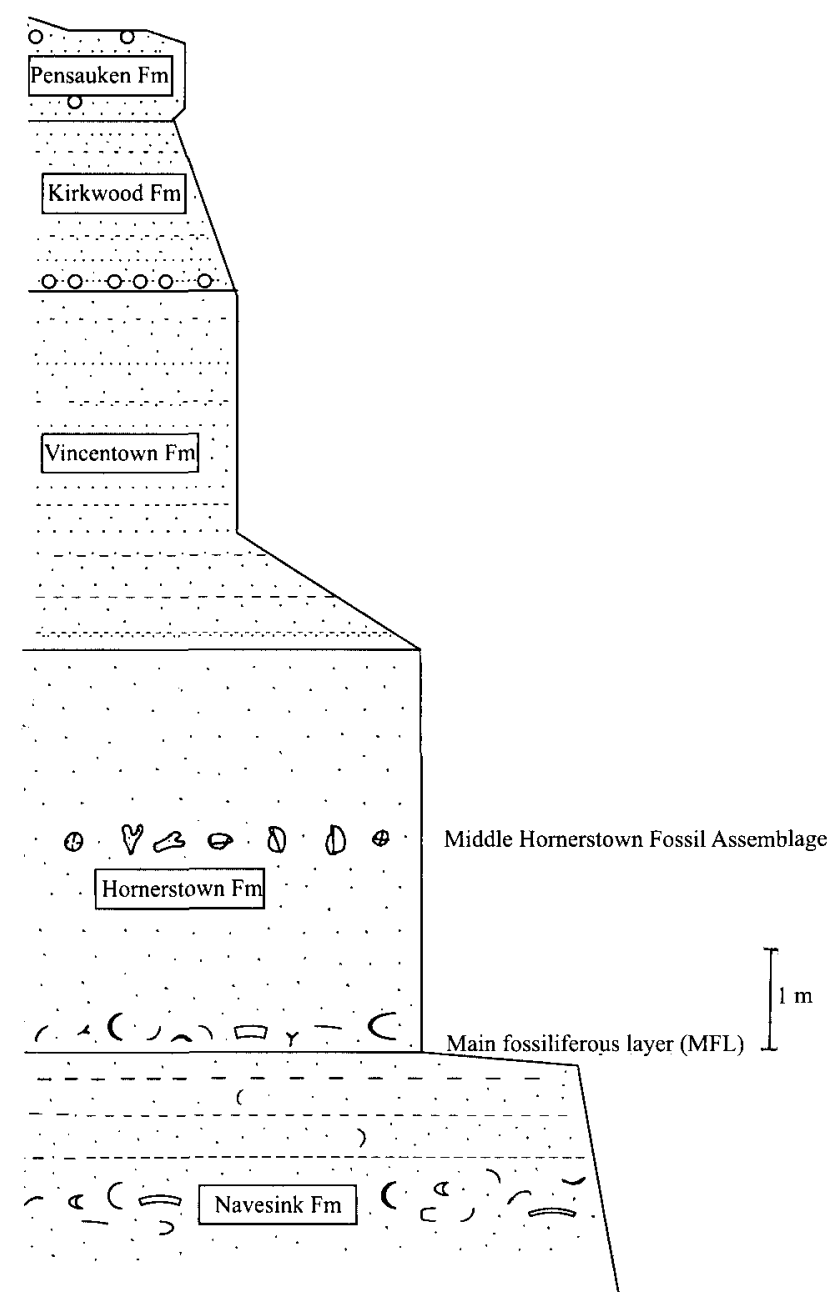

Fig. 3. Stratigraphic section at the Inversand Pit, showing the three major fossil concentrations exposed at the excavation. ments is marked by a cuesta, a low discontinuous ridge often capped by Plio-Pleistocene gravels.

Today, much of this section is exposed only in erosional stream cuts through the Maastrichtian-Danian beds, as well as in one surviving marl mining operation. The available sections have been studied and collected in detail by New Jersey State Museum workers (Gallagher, 1991, 1993; Gallagher et al., 1986). This work has helped reveal some of the palaeoecological details of the faunal changes associated with the $\mathrm{K} / \mathrm{T}$ boundary in this part of the world.

\section{The Inversand Pit}

The mining of greensand marl was a widespread industry in the nineteenth century, and numerous fossils were obtained from the extensive excavations into the marl deposits surrounding the K/T boundary. At this time, glauconite was used as a long-term soil conditioner to enhance the yield of crops. Today, glauconite is still dug at the Inversand Pit, the last commercial greensand mine in existence, for use as a water conditioner. Glauconite is a hydrated potassium/ aluminium/iron silicate with a high cation exchange capacity; it is formed at very low sedimentation rates in low-oxygen marine environments, partly as the result of bioturbation by marine burrowing organisms. The exposures at the Inversand Pit (Fig. 2) are the best available outcrops of the Maastrichtian-Danian section in New Jersey, and the section at the pit stands as an important reference section for the latest Cretaceous and Paleocene in this part of the world.

Three well-defined fossiliferous layers are present 
at the pit, ranging in age from the Maastrichtian oyster bank assemblage in the Navesink Formation at the bottom, through the basal Hornerstown layer to the Danian layer in the middle part of the Hornerstown Formation (Fig. 3).

The fossil faunas bridge the K/T boundary, and in New Jersey the pit provides our best view in outcrop of this critical stratigraphic interval with its record of palaeoecological change. The precise relationship of the Navesink and Hornerstown formations has been a minor controversy here, with United States Geological Survey (USGS) workers favouring an angular unconformity between the two formations at their contact (Owens et al., 1970), while others have proposed differing interpretations (Gallagher et al., 1986; Gallagher, 1993). Currently, we think that the contact between the Navesink and Hornerstown at this pit is more accurately characterised as a disconformity or paraconformity; the precise boundary is smeared out by bioturbation and the contact is usually more obvious from a distance. The contact is certainly a sequence boundary, with the overlying Hornerstown representing the transgressive phase of the next cycle. There may be missing section here, certainly in comparison to the downdip Bass River Core section which has a complete $\mathrm{K} / \mathrm{T}$ sequence in the subsurface, including an impact ejecta layer (Olsson et al., 1997). However, while lithostratigraphically there is a break at the contact in the pit exposure, biostratigraphically the basal fossiliferous layer, occasionally called the Main Fossiliferous Layer (MFL), in the lower Hornerstown Formation contains the last remains of Cretaceous organisms. The time gap is probably an order of magnitude less than the amount of missing time implied by an angular unconformity; during this interval the MFL concentration accumulated as a condensed section lag deposit. Thus, in the pit there is a typical Mesozoic marine community at the bottom in the Navesink Formation, a transitional assemblage in the MFL, and an unusual Danian fauna in the middle of the Hornerstown, giving us some insight into the nature of faunal changes across the $\mathrm{K} / \mathrm{T}$ boundary in New Jersey.

The Navesink shell bed at the base of the pit is characterised by a diversity of molluscs (26 species; Gallagher et al., 1986) associated with the standard concentration of oysters, including Exogyra costata, Pycnodonte convexa, Agerostrea falcata, and Gryphaeostrea vomer. The large arc shell, Cucullaea antrosa, is found at times in the upper part of the Navesink. Rarely, the small brachiopod Choristothyris plicata is encountered. Vertebrates include infrequent shark teeth, teeth and portions of jaw of Enchodus ferox, turtles, mosasaurs, and dinosaurs.
The MFL at the base of the Hornerstown Formation also contains a diverse molluscan fauna (26 species). The commonest amongst them is the thinshelled, fragile oyster Pycnodonte dissimilaris, which can be seen in abundance at outcrop, but which is very difficult to collect intact because of its delicacy. Often, if examined under the microscope, the oyster shells will show a patchy coating of bornite. This mineralisation is probably why they yield an anomalous stable strontium isotope age estimation. The next most abundant invertebrate is Cucullaea vulgaris. Amongst gastropods, Turritella vertebroides and Pyropsis trochiformis are the commonest. There are also ammonite remains of several species, mostly in the form of broken and worn internal moulds. Overall, the molluscan fauna has decidedly Cretaceous affinities.

Vertebrates from the MFL are more diverse than in the other two layers, and include a variety of chondrichthyans, bony fish, turtles, crocodiles, mosasaurs, and birds, for a total of over 30 species. Certain elements of this assemblage, i.e. Squalicorax pristodontus, Enchodus and mosasaurs, are characteristic Cretaceous forms, while other taxa, e.g. turtles and crocodiles, are less distinctively Mesozoic.

Above this horizon an occasional floating shark tooth or rare crocodile remains may be met with, but the section is essentially barren for two metres until another concentration of fossils occurs. This layer is well exposed just now in the new excavation at the pit, and it is significant for how it differs from the underlying beds. Molluscs have been reduced in size, abundance, and diversity ( 6 species). The most abundant bioclasts are sponges, brachiopods, and solitary corals, each group represented by just one species. While the concentration of fossils is clumpy and the shape of the layer somewhat irregular, the continuity of the concentration is apparent and the abundance of the fossils impressive. Vertebrates are rare, with small lamnid shark teeth the most frequently found specimens.

At and above the level of the Hornerstown-Vincentown formational contact, there is in other sites a concentration of the large terebratulid brachiopod Oleneothyris harlani. This remarkable density of brachiopods occurs sporadically where the same level is exposed along strike as far to the south as southeastern North Carolina. In the upper part of the Vincentown Formation, glauconite content decreases and is replaced by quartz sands and patchy occurrences of bryozoan limestone. Diversity rebounds to pre-Danian levels, especially in the limestone beds at the top of the formation; these are interpreted here as a patch reef ecosystem (Gallagher, 1993). 


\section{Discussion}

Mass extinctions in the marine realm are often marked by reductions in the diversity and abundance of plankton. Diversity reduction among the plankton has been documented in the literature for the Frasnian/Famennian event, the Permo-Triassic mass extinction, and the K/T boundary. The effects of this population crash at the base of the food chain should reverberate upwards to higher levels of the trophic pyramid. What evidence can we see in the fossil record of mass extinctions for confirmation of this hypothesis?

Across the $\mathrm{K} / \mathrm{T}$ boundary in eastern North America, there is evidence for a resetting of the evolutionary clock in Danian marine ecosystems which are dominated by faunas of Palaeozoic aspect. Widespread diverse Cretaceous molluscan assemblages are replaced temporarily in the Danian by a sponge-brachiopodcoral dominated assemblage. In particular, fossil concentrations in the $\mathrm{K} / \mathrm{T}$ section of the Atlantic Coastal Plain show a diverse oyster bank ecosystem replaced by a brachiopod-dominated shell gravel where large terebratulids of a single species (Oleneothyris harlani) may form up to $99 \%+$ of the bioclasts. The Oleneothyris Zone can be traced from New Jersey in the north down into southeastern North Carolina at the same level in Paleocene outcrops. A sponge (Peridonella dichotoma) and a solitary coral (Flabellum mortoni) often accompany the brachiopods (see Table 2). Dwarfed bivalves form an insignificant proportion of this fauna.

During and immediately after the Frasnian-Famennian mass extinction, hexactinellid sponges proliferated and diversified while numerous other groups were being decimated (McGhee, 1996). After the most severe extinction event, the Permo-Triassic, demosponges became important in the Triassic. Again, after the Triassic/Jurassic mass extinction, sponges are part of the reef community in the Jurassic.

Sponges are minimalist organisms, able to filter up to 10,000 to 20,000 times their own body volume of water per day (Rigby, 1983). They specialise in extracting smaller bits of nutrients from the water column. In mass extinction events such as the $\mathrm{K} / \mathrm{T}$ event, the kinds of plankton (e.g. foraminifera) left over after the event are generally smaller than the larger and more ornate forms found prior to the extinction. Therefore sponges are likely to be favoured as survivors since they are more effective at filtering out small particles, and at processing large amounts of water for these particles.

Brachiopods are also minimalist organisms. They are able to survive at lower oxygen levels, and in gen- eral have lower food requirements and lower metabolism than other exoskeletonised benthos (Thayer, 1981). The abundance of a single species such as Oleneothyris harlani over a wide area after the $\mathrm{K} / \mathrm{T}$ event suggests it was an opportunistic species that could thrive in the oligotrophic ocean of the Danian.

Hypothesized effects of large body impacts such as reduction in solar radiation reaching the earth's surface, acid rain, and near-destruction of the ozone layer would all have negative effects on the plankton population. As Olsson \& Liu (1993) have shown, only three species of planktonic foraminifera survived the $\mathrm{K} / \mathrm{T}$ boundary. The resulting Danian marine community would have to be adapted to severe reduction in food resources in an oligotrophic ocean, especially in waters closer to the Chicxulub impact site, for example in eastern North America. Such a pattern is demonstrated in the minimalist assemblage of the Danian of the Atlantic Coastal Plain.

The plankton crash also probably affected those organisms that reproduced by means of planktotrophic larvae. Normally, wide dispersal patterns and large numbers of planktotrophic larvae were favoured during times of high planktonic productivity. But, when the planktonic populations crashed at the $\mathrm{K} / \mathrm{T}$ boundary, those organisms that depended upon a developmental stage in the plankton were severely affected. This explains why ammonites, which were planktotrophic reproducers, went extinct while nautiloids, which lay lecithotrophic eggs on the sea bottom, survived. Brachiopods are larval brooders, while sponges are able to reproduce asexually.

Dwarfing among Danian benthos may be explained as a response to lower plankton levels in the post- $\mathrm{K} / \mathrm{T}$ boundary ocean. Danian representatives of Maastrichtian molluscan genera are generally smaller, if they survive at all (e.g. Pycnodonte, Cucullaea). In Russia, echinoids show dwarfing across the $\mathrm{K} / \mathrm{T}$ boundary (Markov \& Solovjev, 1997), and dwarfing has been established as a common feature of earliest Paleocene marine faunas.

The niche of durophagous predator was an important trophic level in the Cretaceous marine food web. There were a variety of shell-crushing carnivores taking advantage of the rich food resources of Cretaceous molluscs and crustaceans. Chimaerids, rays, certain sharks, various bony fish species, some turtles and a few mosasaurs (Globidens, Carinodens) show jaws or dentition adapted for shell crushing. By contrast, marine predators of the Paleocene tend to be more generalised carnivores such as crocodiles or lamnid sharks. Durophagy survived as a niche, but in the Danian opportunistic predators with broader tastes predominated. The scarce resources of the early 
Paleocene oligotrophic ocean affected specialised predators. While mosasaurs are the dominant large predators in the Maastrichtian marine realm, the early Danian beds in New Jersey show an increase in crocodilian fossils. In the aftermath of the extinction, crocodilians became the large dominant marine predators. This 'crocodile spike' reflects an ecological replacement at the level of apical marine predator.

This general pattern of extinction and survival across the $\mathrm{K} / \mathrm{T}$ boundary provides a model for the collapse of marine ecosystems under stresses generated by large-scale environmental disturbance, such as an asteroid impact. Such a pattern should be zonally distributed, reflecting decreasing intensity of impact effects further away from the crater. Preliminary proof for this comes from new Late Cretaceous fossil discoveries in eastern North America; coelacanths and lungfish of Late Cretaceous age were wiped out in this part of the world but survived at the antipodes of the impact in the Indo-Australian region. This idea is also supported by the distribution of other wellknown living fossils such as the bivalve Neotrigonia, various plant families, and marsupials.

\section{Acknowledgments}

I wish to thank David C. Parris (New Jersey State Museum) and the Inversand Company of Clayton (NJ) for their encouragement of this work. Thanks also to the numerous people who have helped in this effort over the years, through assistance in the field, useful discussions, and donation of specimens, including James Barnett, Joseph and Sandra Camburn, Gudni Fabian, Ned Gilmore, Barbara Grandstaff, Paul Hanczaryk, Margaret Martinson, Richard Olsson, Earle Spamer, and Chris Storck. This project is supported through the Horace G. Richards Fund of the Friends of the New Jersey State Museum.

\section{References}

Gallagher, W.B., 1991. Selective extinction and survival across the Cretaceous/ Tertiary boundary in the northern Atlantic Coastal Plain. Geology 19: 967-970.

Gallagher, W.B., 1993. The Cretaceous/Tertiary mass extinction event in the northern Atlantic Coastal Plain. The Mosasaur 5: 75-154.

Gallagher, W.B., Parris, D.C. \& Spamer, E.E., 1986. Paleontology, biostratigraphy, and depositional environments of the Cretaceous-Tertiary transition in the New Jersey Coastal Plain. The Mosasaur 3: 1-35.

Grandstaff, B. S., Gallagher, W. B., Shannon, K., and Parris, D. C., 2000. New discoveries of Late Cretaceous mammals in eastern North America. Journal of Vertebrate Paleontology 20 (supplement to 3): 44A.

Leidy, J., 1858. [Remarks concerning Hadrosaurus foulkii]. Pro- ceedings of the Academy of Natural Sciences of Philadelphia 10: 215-218.

Markov, A.V. \& Solovjev, A.N., 1997. Echinoids at the Cretaceous/Paleogene Boundary. In: Rozanov, A.Yu., Vickers-Rich, P. \& Tassell, C. (Eds): Evolution of the biosphere. Records of the Queen Victoria Museum 104: 35-37.

McGhee, G.R., 1996. The Late Devonian Mass Extinction: the Frasnian/Famennian crisis. Columbia University Press (New York): $303 \mathrm{pp}$.

Miller, K.G., Barrera, E., Olsson, R.K., Sugarman, P.J. \& Savin, S.M., 1999. Does ice drive early Maastrichtian eustacy?. Geology 27: 783-786.

Olsson, R.K. \& Liu, C., 1993. Controversies on the placement of Cretaceous-Paleogene boundary and the K/P mass extinction of planktonic foraminifera. Palaios 8: 127-139.

Olsson, R.K., Miller, K.G., Browning, J.V., Habib, D. \& Sugarman, P.J., 1997. Ejecta layer at the Cretaceous-Tertiary boundary, Bass River, New Jersey (Ocean Drilling Program Leg 174AX). Geology 25: 759-762.

Owens, J.P., Minard, J.P., Sohl, N.F. \& Mello, J.F., 1970. Stratigraphy of the outcropping post-Magothy Upper Cretaceous formations in southern New Jersey and northern Delmarva Peninsula, Delaware and Maryland. United States Geological Survey, Professional Paper 674: 1-60.

Parris, D.C., Grandstaff, B.S. \& Gallagher, W.B., 2001. A lungfish (dipnoan) from the Upper Cretaceous of New Jersey. Journal of vertebrate Paleontology 21 (Supplement to 3): 87A.

Rigby, J.K., 1983. Introduction to the Porifera. In: Rigby, J.K. \& Stearn, C.W. (Eds): Sponges and spongiomorphs. University of Tennessee, Department of Geological Sciences (Knoxville), Studies in Geology 7: 1-11.

Thayer, C.W., 1981. Ecology of living brachiopods. In: Dutro, J.T. \& Boardman, R.S. (Eds): Lophophorates. University of Tennessee, Department of Geological Sciences (Knoxville), Studies in Geology 5: 110-126. 